\title{
Capital Structure and Profitability of Listed Indian Top Companies - An Analytical Study
}

\author{
Dr. B. NAGARJUNA
}

Associate Professor, Dept of Management Studies, Sree Vidyanikethan Institute of Management TIRUPATI

\begin{abstract}
A debt-equity ratio that optimises the company's overall worth or lowers the weighted average cost of capital is regarded as the optimum capital structure. According to previous research studies, companies that avoid debt and depend on equity do better. Short-term loans are bad for a firm's financial health, while long-term debt and equity could be better. Performance is influenced by foreign ownership, the concentration of ownership, and organisational size as well.The researcher wishes to look at the best performing firms on the NSE, therefore 10 companies were chosen to represent each sector, and data on capital structure (debt-equity ratio) and its influence on the company's financial performance was analysed. According to the study, companies with zero debt do well; organizations with excessive debt perform well, and companies with fluctuating debt have a large negative impact or little impact. The researcher suggests that a more thorough examination be conducted to determine whether the high-interest debt is truly necessary and that potential and cost-effective long-term funding solutions be explored. Keywords: Capital Structure, Debt-equity ratio, Earnings per share, Return on assets, return on equity.
\end{abstract}

DOI: $10.7176 / \mathrm{RJFA} / 13-2-01$

Publication date: January $31^{\text {st }} 2022$

\section{INTRODUCTION}

The long-term sources of finances utilised by a business, namely equity shares, preference shares, reserves, and loan capital, are referred to as capital structure. The design of an optimum debt strategy is significantly associated to capital structure, which is considered crucial in corporate financial management. Changing a company's financial structure is difficult since it involves balancing various opposing considerations, such as risk and profitability. The capital structure is a company's choice of how much of its money comes from its owners (equity capital) and how much comes from outsiders (debt capital) such as debentures and other long-term loans (Ross, Westerfield, and Jordan 2001). The sources of each component is depicted in the Table 1.

\begin{tabular}{|c|c|}
\hline \multicolumn{2}{|c|}{ Table 1. Components of Long-term Finance - Sources } \\
\hline Shareholders' or Owner's or Internal Fund & Borrowed or External Funds \\
\hline Equity Capital by issue of equity shares & Debt by issue of Debentures \\
\hline Preference Capital by issue of preference shares & Long-term Loans from Banks \\
\hline Retained Earnings & Public Deposits \\
\hline \multicolumn{2}{|c|}{ Source: Author } \\
\hline
\end{tabular}

A debt-to-equity ratio that maximises the company's overall worth or lowers the weighted average cost of capital is referred to as an ideal capital structure. The degree of financial leverage at which a company's securities have a better market value or the cost of borrowing is lower than at other levels of leverage is known as the optimal capital structure.

Capital structure decisions have a significant and positive influence on profitability and firm value because they raise value by the present value of tax savings arising from debt utilisation. It does not imply that the firm can operate effectively with 100 percent debt capital; because of the increased risk of financial problems, excessive debt consumption may result in a decrease in the value, wealth, or profit of its owners.

Some theories of capital structure are briefly described as follows:

\subsection{Miller and Modigliani's First Proposition without taxes:}

Debt has no impact on whether or not shareholders become richer or poorer. The tax benefit and the risk of utilising debt must exactly cancel out for this idea to make sense. According to the researchers, the firm's value remains constant regardless of the capital structure. By borrowing on behalf of shareholders, managers will not be producing or destroying wealth, according to MM, because shareholders might do so themselves. Alternatively, the shareholder might borrow money from a bank and invest in an unlevered company with the same payoff as the levered company.

\subsection{Miller and Modigliani's Second Proposition with taxes}

If interest is deductible under the income tax laws, it lowers the amount of corporation tax or government debt owed. This means that debt's tax advantage leads to higher returns on equity (ROE) and firm value. For example, if the corporate tax rate is $40 \%$, then every rupee of debt adds at least 40 paise to the firm's worth. 


\subsection{Trade-off Theory}

According to trade-off theory, enterprises are partially financed by debt and partly by equity, with the decision based on a cost-benefit analysis. If a firm selects debt financing, it must weigh the tax benefits of debt against the consequences of bankruptcy and financial distress, as well as the costs of debt financing. It's worth noting that when we say "bankruptcy expenses", we include both direct and indirect costs, as well as agency costs. This implies that tax rates and the cost of bankruptcy are more likely to impact capital structure.

\subsection{Pecking Order Theory}

The pecking order theory (POT) is all about funding organisations in a certain sequence, from safer to riskier. This implies that internal financing is preferred over external sources like convertible bonds, and hybrid securities are preferred over stock. Unlike the trade-off theory, the POT does not enforce a goal debt-to-equity ratio; instead, greater debt is included in external finance. Contrary to popular belief, evidence suggests that this principle applies less to small businesses than to large corporations. In his work, the capital structure conundrum, Myers, S. C. (1984) developed the Pecking order hypothesis, in which he proposes that enterprises should seek funding in the following sequence: internal capital, borrowed capital, and lastly, equity capital. In a nutshell, companies would prefer internal finance versus external borrowing.

\subsection{Market Timing Theory}

Firms issue new stock when their share price is high and repurchase their shares when their share price is low, according to the market timing theory of capital structure. Equity market timing may be divided into two types, both of which produce the same capital structure dynamics. The first version highlights managers' and investors' rationality. Managers raise stock when the cost of equity is extremely low, according to the second version, because they believe investors are irrational.

\subsection{The Agency Theory of Capital Structure}

The agency theory of capital structure is based primarily on conflicts between managers and shareholders, because managers operate primarily for their own gain, whereas they must act for the interest of shareholders. Dividend payments to shareholders lower the resources under managers' control, and hence management authority. Debt reduces the likelihood of bankruptcy by reducing the dispute between management and stock holders.

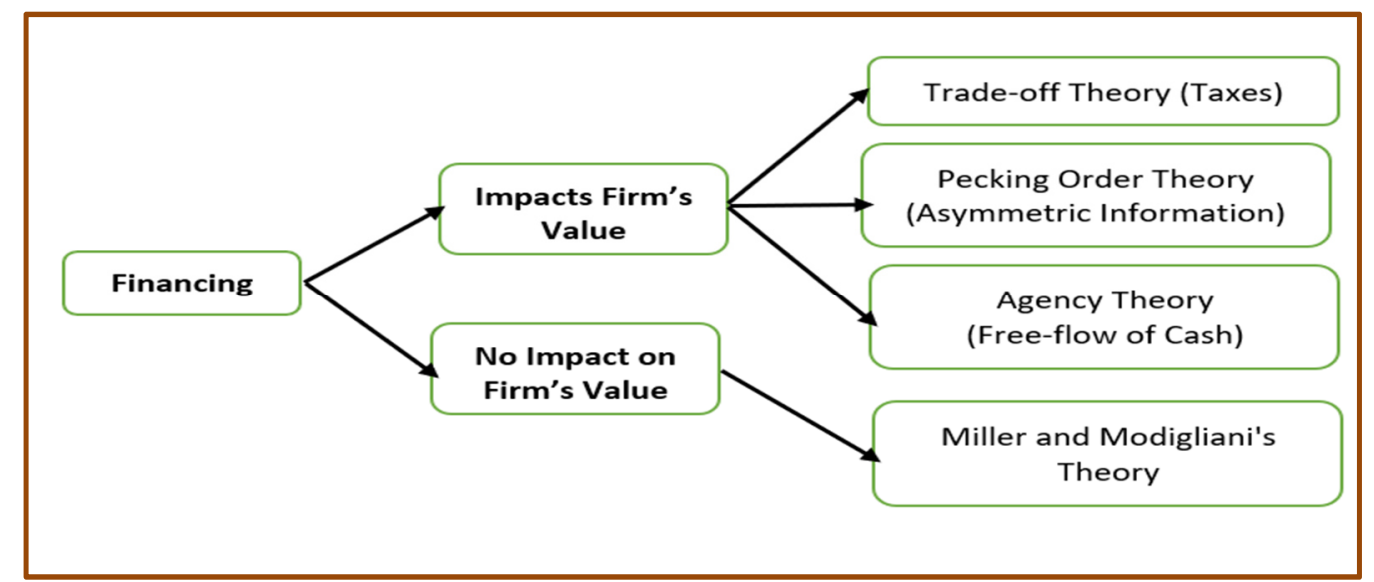

Figure 1. Capital Structure Theories - Classification; Source: Seadin Xhaferi \& Besa Xhaferi (2015)

\subsection{Conclusion}

Decisions on capital structure have a large and positive impact on profitability and firm value because they increase value by the present value of tax savings resulting from debt use. An optimum capital structure is defined as a debt-to-equity ratio that optimises the company's total worth or minimises the weighted average cost of capital. The pecking order theory (POT) is concerned with supporting organisations in a certain order, from safer to riskier. This means that internal funding is preferable to external sources such as convertible bonds, and hybrid securities are preferable to stock. This notion appears to apply less to small enterprises than to huge organisations, according to evidence. The struggle between managers and shareholders is central to the agency theory of capital structure.

\section{REVIEW OF LITERATURE}

Review of literature is presented under three following:

a) Review on research works revealing positive effect.

b) Review on research works revealing negative or no effect. 
c) Review on research works revealing positive and negative or mixed effect. The following is the presentation of the review of literature as stated above:

\subsection{Review on research works revealing positive effect.}

Khalid Ashraf CHISTI, Khursheed ALI \& Mouh-i-Din SANGMI, (2013) gave an attempt in this study to determine the influence of capital structure on a firm's profitability. The vehicle sector is the centre of this research, and 10 organisations are utilised as a sample. The study's reference period is five years, and it is entirely based on secondary data gathered from a variety of sources. The researchers used the examination of numerous ratios to fulfil the study's goals. The study's findings show that capital structure has a statistically significant influence on a company's profitability.

Goyal A.M. (2013) also investigated the influence of capital structure on the profitability of public sector banks in India that are listed on the national stock exchange from 2008 to 2012. To establish a relationship between Return on Equity, Return on Assets, and EPS with capital structure, regression analysis was utilised. The data show that short-term debt has a positive association with profitability as measured by ROE, ROA, and EPS.

Taqi M, Ajmal M \& Parvez A (2016) stated from their research that finance choices are regarded as one of the most critical areas for finance managers to assess their influence on a company's capital structure and financial performance. The capital structure of a corporation is the composition or structure of its obligations, and it has an impact on the company's behaviour, performance outcomes, and value. The findings reveal that long-term debt and equity have a favourable and significant influence on financial performance, but short-term debt has a negative impact.

Narinder Pal Singh \& Mahima Bagga (2019) observed many studies that were undertaken to investigate the impact of capital structure on business profitability, but most of them are from outside the country and a few research works are from India. Descriptive statistics, correlation, and multiple panel data regression models were used to examine the data in their research. The researchers find that capital structure has a strong positive influence on a firm's profitability.

According to the findings of Abor J. (2005), prosperous businesses are more likely to rely on debt as a primary source of funding. In Ghana's situation, short-term debt accounts for a large share of the debt (85 percent). The findings reveal a substantial positive relationship between total debt to total assets and return on equity.

Addae, A. A., Nyarko-Baasi, M., \& Hughes, D. (2013) made a research during the years 2005 to 2009, and investigated on the relationship between capital structure and profitability of Ghanaian listed companies. According to a study of the literature, profitability and capital structure have either a positive, negative, or neutral connection. The findings also found that Ghanaian listed companies used short-term debt more frequently than long-term debt.

Alqirem, R., et al (2020) collected and examined secondary data from financial records relating to all insurance companies registered on the Jordanian market. According to the conclusions of their study ownership concentration, foreign ownership, and organisation size all have an impact on organisational performance. Furthermore, manipulating earnings has a beneficial impact on organisational performance as measured by ROA, $R O E$, and EPS.

Gambo, E. M. J, Abdul-Rahman, A \& Ahmad, M. M (2016) investigated the influence of capital structure on financial performance of enterprises in the Nigerian cement sector. Ex-post factor analysis of the influence of long and short-term indebtedness on Return on Assets (ROA) and Return on Equity (ROE) was used in this study (ROE). The study revealed, however, that enterprises in the cement industry's performance is not optimum due to their incapacity to use indebtedness in their capital structures. Long-term debt should be used in cement businesses' capital structures since it improves their financial performance.

Herciu, M., \& Ogrean, C. (2017) observed that every enterprise has a unique balance sheet structure, and the focus of this research is to determine some optimal levels in order to improve profits. The companies chosen are among the Fortune Global 500's most profitable non-financial firms. As a measure (reflection) of capital structure, the debt-to-equity ratio is applied. The major findings concern increasing firm profitability by utilising an ideal liability and equity structure. In the technology, health-care, and telecommunications sectors, there are very significant and positive correlation between ROE and debt-to-equity.

Semuel, H \& Widjojo, L (2016) analysed the impact of capital structure on profitability. The data for this research paper was gathered from 29 construction and property enterprises between 2009 and 2013. Structural equation modelling is used for the method of analysis. The impact of short-term debt on profitability is favourable. According to the findings, property and construction firms in Indonesia should place greater reliance in shortterm loan sources such as property purchasers, subcontractors, and material suppliers to increase their profitability.

Anarfo, E.B. and Appiahene, E. (2017) researched the influence of capital structure on bank profitability in Africa is investigated in this article. The Debt Ratio (DR) was used as a measure of capital structure in the study, which used dynamic panel regression robust analysis and data from 37 countries in SSA (Sub-Sahara Africa). 
Bank profitability was measured using Risk Adjusted Return on Asset (RAROA), Risk Adjusted Return on Equity (RAROE), and Net Interest Margin (NIM). According to the findings, a bank's capital structure is a determinant of profitability. Size, physical assets, growth, taxes, and interest rate are all factors that have a substantial impact on a bank's profitability.

Movalia, N.P. (2015) analysed the debt-equity ratio of 14 tyre manufacturing businesses listed on the BSE and NSE. MRF, Apollo Tyres, Dunlop India, and Modi Rubber are among the firms that were investigated in this study. Capital structure (debt-equity ratio) and profitability of tyre companies with ideal debt-equity ratio have a significant relationship. The appropriate debt equity ratio contributes to a company's increased profitability.

\subsection{Review on research works revealing negative effect.}

Sorana Vătavu (2015) stated that the research objectives of this paper is to figure out how capital structure affects financial performance in 196 Romanian firms registered on the Bucharest Stock Exchange. The findings show that enterprises in Romania perform better when they avoid debt and rely on equity. Manufacturing businesses, on the other hand, appear to lack adequate internal capital to make lucrative investments and to make good use of their assets.

El - Sayed Ebaid, I. (2009) did the first research in Egypt to look at the relation between leverage and business performance. The findings show that capital structure selection has little to no influence on a firm's success. Based on a sample of non-financial Egyptian listed enterprises from 1997 to 2005, using three accounting-based financial performance indicators that is return on equity (ROE), return on assets (ROA), and gross profit margin.

Ali, A., \& Faisal, S. (2020) found that the capital structure of a company has a negative association with its profitability, resource utilisation, and liquidity. Due to low demand and reduced pricing, which are the result of external circumstances, Saudi petrochemical industries are underutilizing their resources. Other aspects, such as the scale of the company, focusing on profitable streams, raising turnover, and limiting production costs, must be considered in order to enhance the petrochemical sector's overall performance in Saudi Arabia.

Chechet, I. L., \& Olayiwola, A. B. (2014) studied with a sample of seventy (70) out of a population of two hundred and forty-five enterprises listed on the Nigerian Stock Exchange (NSE) for a period of ten (10) years: 2000-2009, this research examined at capital structure and profitability of Nigerian listed firms from an Agency Cost Theory viewpoint. The results demonstrate that DR (Debt Ratio) has a negative relationship with PROF (Profit), the only dependent variable, whereas EQT (Equity) has a positive relationship with PROF (Profit).

Dawar, V. (2014) aimed at to examine at the influence of capital structure decision on company performance in India, a developing country. A ten-year period of data (2003-2012) on the sample units is analysed using a fixed effect panel regression model. Empirical findings demonstrate that leverage has a unfavourable impact on Indian enterprises' financial performance, which contradicts agency theory's assumptions. The findings will help practitioners and analysts understand why leverage is negatively connected with company performance in India's bank-dominated debt financing system.

The influence of debt on corporate profitability in non-finance listed businesses on the Vietnam stock exchange is investigated in this research (Ngo, T. V., Tram, H. T., \& Vu, T. B. 2020). The research sample covers 118 non-financial publicly traded firms for a nine-year period, from 2009 to 2017 . The study's control variables include firm sizes, tangible assets, growth rate, and taxes. Debt has a statistically significant detrimental impact on a firm's profitability, according to the findings.

Tailab, M. (2014) researched on the effect of capital structure on profitability of the companies. For this research a total of 30 Energy American companies were studied during a nine-year period, from 2005 to 2013. Smart PLS (Partial Least Square) version 3 was used to analyse the data. According to the findings, total debt has a considerable negative impact on ROE and ROA, although sales size only has a significant negative influence on ROE. Long-term debt, debt-to-equity ratio, and size in terms of total assets and profitability were shown to have no significant negative or positive association.

Hamid, M.A., Abdullah, A. and Kamaruzzaman, N.A. (2015) analysed the impact of capital structure on profitability of 46 family enterprises and 46 non-family firms in Malaysia is investigated in this study. The shortterm debt ratio, long-term debt ratio, and debt ratio were utilised in this study to examine the impact of capital structure on profitability as assessed by return on equity. The results reveal that debt ratio is adversely and strongly associated to profitability, based on $276(46+46=92 * 3$ years $=276)$ firm year observations of Malaysian listed businesses during three years, 2009 to 2011. The findings imply that profitable businesses rely on equity as their primary source of funding. The findings revealed that a higher leverage situation is linked to worse profitability.

\subsection{Review on research works revealing mixed effect.}

Hajisaaid, A. (2020) made a study for the period from 2009 to 2018 on the association between capital structure and profitability of eight Saudi Arabian enterprises in the basic materials industry. Return on equity (ROE) is the dependent variable, while short-term debt to total assets ratio (SDA), long-term debt to total assets ratio (LDA), and total debt to assets ratio (TDA) are the independent variables. The findings show a negative association 
between SDA and profitability, which is consistent with previous research by Hamid and colleagues (2015) and Abeywardhana (2015), as well as a positive relationship between total debt (TDA) and profitability.

CO Huong Thi Thanh, et al (2021) researched to examine into and quantify the influence of capital structure on company profitability in developing economies. From 2015 to 2019, the study sample contains eighteen rubber firms that were listed on the Vietnam stock market. The long-term debt-to-assets ratio has a negative impact on profitability but a positive impact on the return on equity (ROE) ratio, according to the findings. The findings also demonstrate that business size and sales growth have a beneficial influence on profitability.

Reema Monga (2018) studied with an objective of this study is to ascertain the impact of capital structure on firm's profitability. Data has been collected from the secondary sources i.e., from the annual reports of the selected sample companies. Results of the analysis show that there is a negative association between capital structure and profitability except for the association with gross profit ratio.

Chandrika P D \& RabindraKumar S (2018) observed that financing decisions is one of the most significant aspects of financial management for increasing shareholder wealth. Firms can finance their assets using either debt or equity capital. In this study, the researchers analysed secondary data and selected 50 of the world's leading manufacturing organisations. The study concludes that capital structure and profitability have a significant relationship, and capital structure has a significant impact on financial performance. According to the authors, it is found that a $1 \%$ change in capital structure will result in a $10 \%$ change in ROE. Return on equity is the most fundamental measure of profitability, yet only $10 \%$ of it is influenced by these factors. The remaining $90 \%$ change might be attributable to other factors such as market rivalry, the status of the economy, corporate promotion, which effects volume of sales, cost of raw materials, labour, and so on, and whose impact is not taken into account in this study.

Javed, T., Younas, W., \& Imran, M. (2019) investigated the influence of capital structure on the performance of 63 firms listed on the Karachi Stock Exchange. The findings revealed that there is a relationship, however the direction of the relationship is inconsistent. It has been demonstrated that capital structure has an influence on business performance, hence managers should exercise caution when making capital structure decisions.

Zeitun, R., \& Tian, G. G. (2007) by using a panel data sample of 167 Jordanian enterprises from 1989 to 2003, this study will look at the impact of capital structure on corporate performance. The findings revealed that a company's capital structure had a considerable negative influence on its performance indicators, both accounting and market-based. Also discovered that the ratio of short-term debt to total assets (STDTA) has a favourable impact on the market performance metric.

Qayyum, N. U., \& Noreen, U. (2019) analysed the impact of capital structure on Islamic and conventional bank profitability is examined in this study. During the years 2006-2016, a sample of 10 banks was obtained. The capital structures of both types of banks were comparable, except for the size of the institutions, which was greatly different. Both conventional and Islamic banks' capital structures were shown to be adversely connected with ROA, according to the studies. The capital structure of both conventional and Islamic banks, on the other hand, was positively connected to $R O E$.

Nasimi, A. N. (2016) did research with the purpose to investigate the impact of capital structure on business profitability. A sample of 30 enterprises from the FTSE-100 index of the London Stock Exchange were chosen for the goal of experimentally studying the influence of capital structure. The study's data was collected from 2005 to 2014. The influence of capital structure on company performance was investigated using the multiple regression analysis approach. Interest Coverage has a positive significant influence on ROA, ROE, and ROIC, whereas DE has a positive significant impact on ROE but a negative significant impact on ROA and ROIC, according to the findings. To reach the desired degree of efficiency, the study indicated that an optimal capital structure, effective resource usage, and resource allocation should be used.

Riaz, S (2015) investigated the impact of capital structure (finance decisions) on financial performance. Data was gathered over a 5-year period from the annual audited reports of the 28 businesses listed on the KSE (Karachi Stock Exchange) in Pakistan's chemical sector (2009-2013). Correlation and panel least square regression analysis were utilised to investigate the relationship between capital structure and corporate financial performance. TDR (Total Debt ratio) and STDA (Short Term Debt to total Assets) have a significant negative influence on the financial performance of firms measured by ROA (Return on Assets), according to the results of the statistical analysis. The relationship between ROA and TIE (Times interest earned) ratio is significant and beneficial. On the other side, DER (Debt-Equity Ratio) and LTDA (Long Term Debt to total Assets) have a minor but unfavourable influence on ROA.

Yegon, C., et al. (2014) by the use of panel data gathered from businesses registered on the Nairobi Stock Exchange from 2004 to 2012, this research investigates the relationship between capital structure and company profitability in Kenya's banking industry. Short-term debt has a statistically significant positive association with profitability, whereas long-term debt has a statistically significant negative link with profitability. 


\subsection{Review Summary}

The researchers discovered that a firm's capital structure had a significant positive influence on its profitability. Short-term loans are detrimental to financial performance, however long-term debt and equity are desirable. Foreign ownership, concentration of ownership, and organisational size all have an impact on performance. In the technology, health-care, and telecommunications industries, there is a positive correlation between ROE and debtto-equity. According to researchers, firms in Romania and Nigeria perform better when they avoid debt and rely on equity. It was also observed that a company's capital structure had a negative relationship with its profitability, resource utilisation, and liquidity. According to their findings, total debt has a strong and negative impact on ROE and ROA. The majority of studies revealed mixed results, for example, if a handful of profitability measures such as gross profit margin rate (GPR), net profit margin rate (NPR), Earnings per Share (EPS), Return on Assets (ROA), and Return on Equity (ROE) are studied, some measures have a positive and significant relationship with capital structure while others do not.

\subsection{Research Questions}

The following research questions are posed as a result of the preceding literature review:

2.5.1 Does the capital structure (debt-equity ratio) of Indian enterprises have an impact on their profitability?

2.5.2 Does capital structure have the same influence across all sectors in the country?

2.5.3 Is it necessary for a company to take on debt in order to be profitable?

2.5.4 Does capital structure have a positive and significant impact on the financial performance of top and leading companies across industries?

2.5.5 Does capital structure have the same degree and direction of influence on different profitability measures?

\section{OBJECTIVES OF THE RESEARCH}

The following are the purposes of the research study:

3.1 To study the theories of capital structure in brief to understand the concepts.

3.2 To find whether debt is essential for the Indian corporate companies to improve their financial performance.

3.3 To study the impact of capital structure (debt-equity ratio - DER) on the profitability of the selected Indian companies across different sectors.

\section{SIGNIFICANCE AND SCOPE OF THE STUDY}

Financial management was often disregarded since it only dealt with the procurement of funds, but it has since evolved and grown to include all areas of a business, including the acquisition, deployment, and control of funds. As a result, it has a direct influence on the performance of the business organisation. The cost of bankruptcy is caused by an over reliance on debt. Similarly, under-utilizing debt reduces a company's profit potential. The finance manager should select an optimal capital mix that will boost financial results.

\section{RESEARCH METHODOLOGY}

The research framework for this research paper is described as follows:

\subsection{Sample selection and sampling units}

The Sampling Unit is an NSE-listed firm (National Stock exchange). The following Table2 lists the firms that were chosen as sample companies. All of the firms chosen are market leaders in their respective fields. Each sector is represented by ten firms. Because there are no organisations with debt in the IT (information technology) industry, TCS (Tata Consultancy Services) Ltd and Infosys Ltd were chosen for the research. Reliance Industries Ltd. (RIL) produces a variety of products and services and is a "mixed-sector company." Further, from the banking sector, State Bank of India Ltd (SBI), the export sector, Adani Enterprises Ltd, the aviation sector, Indigo (Interglobe Aviation) airlines, the automobile sector, Ashok Leyland Ltd, the chemicals industry, BASF Ltd, the fertiliser industry, Chambal Fertilisers Ltd, and the pharmaceutical industry, Glenmark Pharma Ltd, were chosen for the study. Proper care is taken while selecting the sampling units so that all the companies do have some amount of debt in their total capital, except in the IT industry, where there is no IT company using debt. 


\begin{tabular}{|c|l|c|}
\hline \multicolumn{3}{|c|}{ Table 2. Sampling Units for the Study } \\
\hline S. No. & \multicolumn{1}{|c|}{ Selected Company Name } & Sector \\
\hline 1 & TCS (Tata Consultancy Services) Ltd & IT \\
\hline 2 & Infosys Ltd & IT \\
\hline 3 & Reliance Industries Ltd (RIL) & Bixed \\
\hline 4 & SBI (State Bank of India) Ltd & Export \\
\hline 5 & Adani Enterprises Ltd & Aviation \\
\hline 6 & Interglobe Aviation (INDIGO) Ltd & Automobile \\
\hline 7 & Ashok Leyland Ltd & Chemicals \\
\hline 8 & BASF INDIA Ltd & Fertilisers \\
\hline 9 & Chambal Fertilisers Ltd & Pharma \\
\hline 10 & Glenmark Pharma Ltd & Source: Author \\
\hline \multicolumn{2}{|c|}{} \\
\hline
\end{tabular}

\subsection{Data type and sources}

The research is based on secondary data, which was gathered in the form of corporate fact sheets for the selected firms from https://www.equitymaster.com/. As a result, the obtained data is cross-verified with information from the firms' annual reports. Similarly, research papers were collected from published journals to complete the review of literature on the topic.

\subsection{Dependent and Independent variables to study}

The company's capital structure is treated as an independent variable, whereas profitability is treated as a dependent variable. The debt-equity ratio (DE R) is used to represent a company's capital structure. Profitability is measured in a different method, such as GPR, NPR, PSR, ABVPS, EPS, ROA, ROE, and ROC. Table 3 shows the formulas for all of them.

\begin{tabular}{|c|l|l|}
\hline \multicolumn{1}{|c|}{ Table 3. Variables \& Formulae } \\
\hline S. No. & \multicolumn{1}{|c|}{ Variables } & \multicolumn{1}{c|}{ Formula } \\
\hline 1 & Debt-Equity Ratio (DE R) & Long term debts / Owners' equity \\
\hline 2 & Gross Profit Ratio (GPR) & Gross profit*100/Net sales \\
\hline 3 & Net Profit Ratio (NPR) & Net profit*100 / Net sales \\
\hline 4 & Price to Sales (PSR) & Share Price *100 / Total Sales \\
\hline 5 & $\begin{array}{l}\text { Adj. BV per Share Rs } \\
\text { (ABVPS) }\end{array}$ & $\begin{array}{l}\text { Adjusted increased Asset - Adjusted increased Liability) / (Total } \\
\text { number of Equity Shares }\end{array}$ \\
\hline 6 & Earnings per Share (EPS) & Net Income after Taxes / Total Number of Shares Outstanding \\
\hline 7 & Return on Assets (ROA) & Net Income*100 / Average of Total Assets \\
\hline 8 & Return on Equity (ROE) & Net Income*100 / Shareholders' Equity \\
\hline 9 & Return on Capital (ROC) & (Net Income - Dividends) *100 / (Debt + Equity \\
\hline
\end{tabular}

\subsection{Data period}

Data on the above-mentioned factors is used to continue the study analysis for the five fiscal years from 2017 to 2021.

\subsection{Data classification and tabulation}

Each company's data is categorised and tabulated in cross tables, with years in the rows and dependent and independent variables in the columns.

\subsection{Statistical tools}

To analyse the data, Karl Pearson coefficient of correlation and test of correlation at $5 \%$ level of significance are employed, as well as graphical display when necessary.

\subsection{Research hypotheses}

The following statements of null hypotheses are formulated to test:

5.7.1 There is no significant correlation between DE R and GPR.

5.7.2 There is no significant correlation between DE $R$ and NPR

5.7.3 There is no significant correlation between DE R and PSR

5.7.4 There is no significant correlation between DE R and ABVPS

5.7.5 There is no significant correlation between DE $R$ and EPS 
5.7.6 There is no significant correlation between DE R and ROA

5.7.7 There is no significant correlation between DE R and ROE

5.7.8 There is no significant correlation between DE R and ROC

The research hypotheses are tested for each of the selected companies.

\section{THEORETICAL MODEL}

The following theoretical is proposed to perform the analysis:

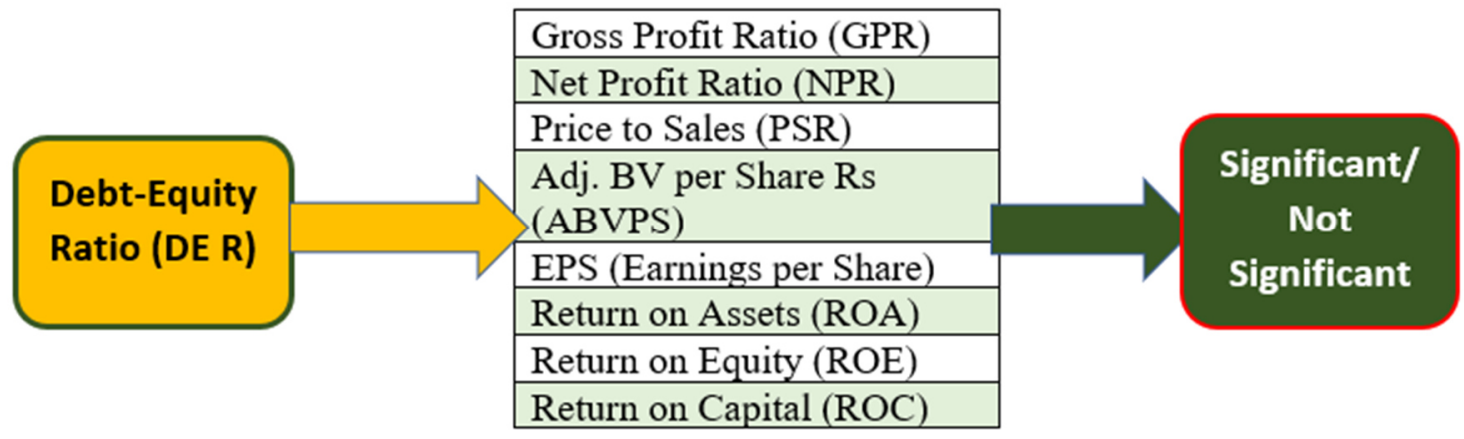

Figure 2. Theoretical Model; Source: Author

Karl Pearson coefficient of correlation is determined between DE R and each of the dependent variables to know the direction (positive or negative) of the variables and test of hypothesis is performed at $5 \%$ level of significance to find whether it is significant. This procedure is done for each of the 10 selected companies and then inferences are drawn. Then overall insights like in which industry/sector the impact of capital structure is significant and positive and negative or insignificant.

\section{RESEARCH RESULTS}

The research results are presented as follows:

\subsection{The Case of TCS Ltd}

The debt-equity ratio (DER) of the company and the different profitability ratios, namely, gross profit margin in percentage, net profit margin in percentage, price (share price) to sales ratio in percentage, adjusted book value per share in rupees, earnings per share in rupees, return on assets in percentage, return on equity in percentage, and return on capital in percentage for the period of five accounting years from 2017 to 2021 are presented in table 4.

\begin{tabular}{|c|c|c|c|c|c|c|c|c|c|}
\hline \multicolumn{2}{|c|}{ Table 4. TCS Ltd - DER \& Profitability Ratios } \\
\hline YEAR & DE Ratio & $\begin{array}{c}\text { GP } \\
\text { Ratio } \%\end{array}$ & $\begin{array}{c}\text { NP } \\
\text { Ratio } \%\end{array}$ & Price/Sales Ratio \% & Adj. BV per Share Rs & EPS Rs & $\begin{array}{c}\text { ROA } \\
\%\end{array}$ & $\begin{array}{c}\text { ROE } \\
\%\end{array}$ & $\begin{array}{c}\text { ROC } \\
\%\end{array}$ \\
\hline 2017 & 0 & 27.4 & 22.3 & 4 & 233.1 & 133.8 & 26.3 & 30.6 & 40 \\
\hline 2018 & 0 & 26.4 & 21 & 4.3 & 230.1 & 135.2 & 25.2 & 30.4 & 40.1 \\
\hline 2019 & 0 & 27 & 21.5 & 6.9 & 241.8 & 84.1 & 28.3 & 35.3 & 46.7 \\
\hline 2020 & 0 & 26.8 & 20.7 & 4.5 & 227.4 & 86.5 & 28.3 & 38.6 & 51.3 \\
\hline 2021 & 0 & 27.6 & 19.8 & 5.6 & 233.7 & 88 & 26.2 & 37.7 & 51.4 \\
\hline \multicolumn{7}{|c|}{ Source: https:/www.equitymaster.com/ } \\
\hline
\end{tabular}

It's found that debt is zero in TCS Ltd, and hence DER is zero. However, the performance in the selected variables was positive but fluctuated very widely. This can be clearly visualised in Figure 3. 


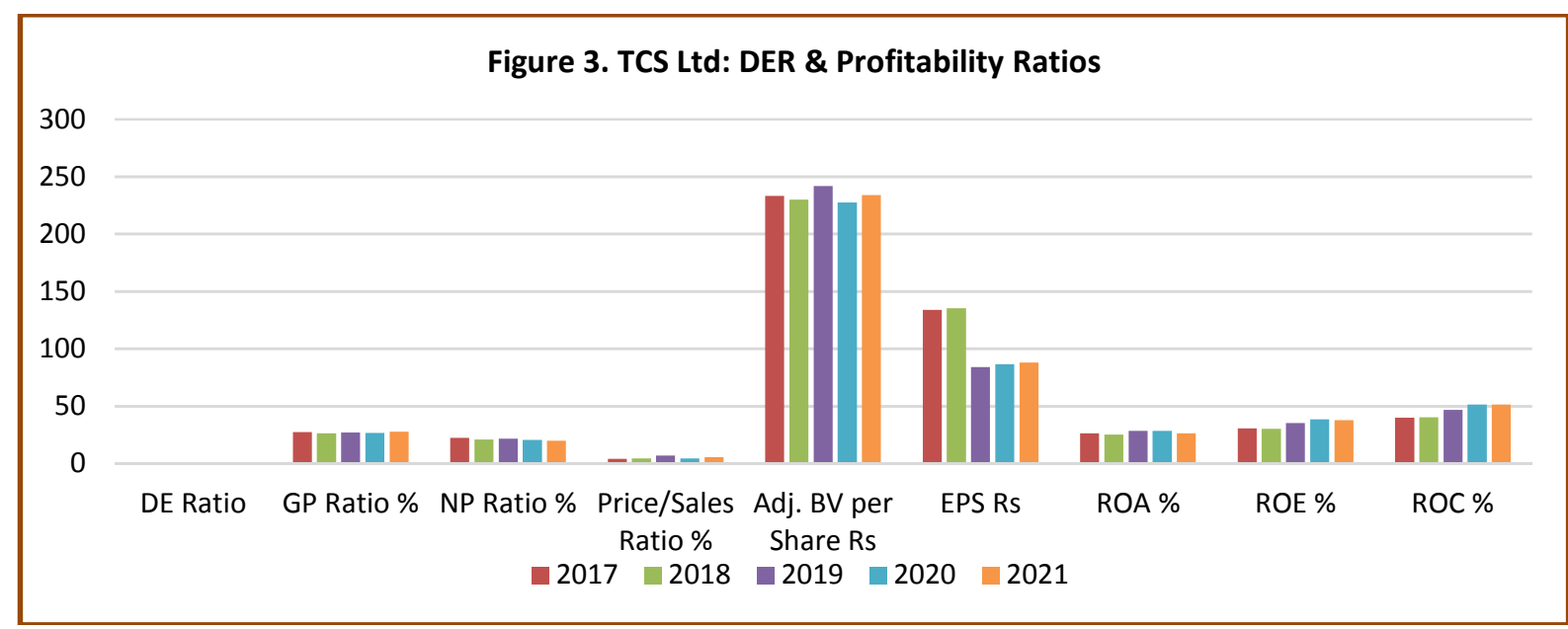

This implies that in the case of profit-making company, the use of debt is irrelevant in earning profit when vision is perfect and leadership is effective in tracing business opportunity. The profitability of the company has been facing hiccups due to the dynamics of business environment.

\subsection{The Case of Infosys Ltd}

The debt-equity ratio (DER) of the company, Infosys Ltd and the different profitability ratios, namely, gross profit margin in percentage, net profit margin in percentage, price (share price) to sales ratio in percentage, adjusted book value per share in rupees, earnings per share in rupees, return on assets in percentage, return on equity in percentage, and return on capital in percentage for the period of five accounting years from 2017 to 2021 are presented in table 5 .

\begin{tabular}{|c|c|c|c|c|c|c|c|c|c|}
\hline \multicolumn{10}{|c|}{ Table 5. Infosys Ltd - DER \& Profitability Ratios } \\
\hline YEAR & $\begin{array}{c}\text { DE } \\
\text { Ratio }\end{array}$ & $\begin{array}{c}\text { GP } \\
\text { Ratio \% }\end{array}$ & $\begin{array}{c}\text { NP } \\
\text { Ratio \% }\end{array}$ & $\begin{array}{c}\text { Price/Sales } \\
\text { Ratio \% }\end{array}$ & $\begin{array}{c}\text { Adj. BV per } \\
\text { Share Rs }\end{array}$ & $\begin{array}{c}\text { EPS } \\
\text { Rs }\end{array}$ & $\begin{array}{c}\text { ROA } \\
\%\end{array}$ & $\begin{array}{c}\text { ROE } \\
\%\end{array}$ & $\begin{array}{c}\text { ROC } \\
\%\end{array}$ \\
\hline 2017 & 0 & 26.6 & 21 & 3.6 & 163.7 & 62.9 & 17.4 & 20.9 & 29 \\
\hline 2018 & 0 & 26.8 & 22.8 & 3.2 & 154.1 & 74.1 & 20.5 & 24.8 & 31.4 \\
\hline 2019 & 0 & 24.4 & 18.6 & 5.4 & 153.9 & 35.5 & 18.5 & 23.8 & 32.5 \\
\hline 2020 & 0 & 24 & 18.3 & 3.2 & 154.9 & 39.2 & 18.5 & 25.5 & 34 \\
\hline 2021 & 0 & 27.4 & 19.3 & 4.2 & 180.7 & 45.8 & 18.3 & 25.6 & 35.3 \\
\hline \multicolumn{10}{|c|}{ Source: https://www.equitymaster.com/ } \\
\hline
\end{tabular}

It's observed that debt is zero in Infosys Ltd. and hence DER is zero. However, the performance in the selected variables was positive but fluctuated very widely. This can be clearly visualised in Figure 4.

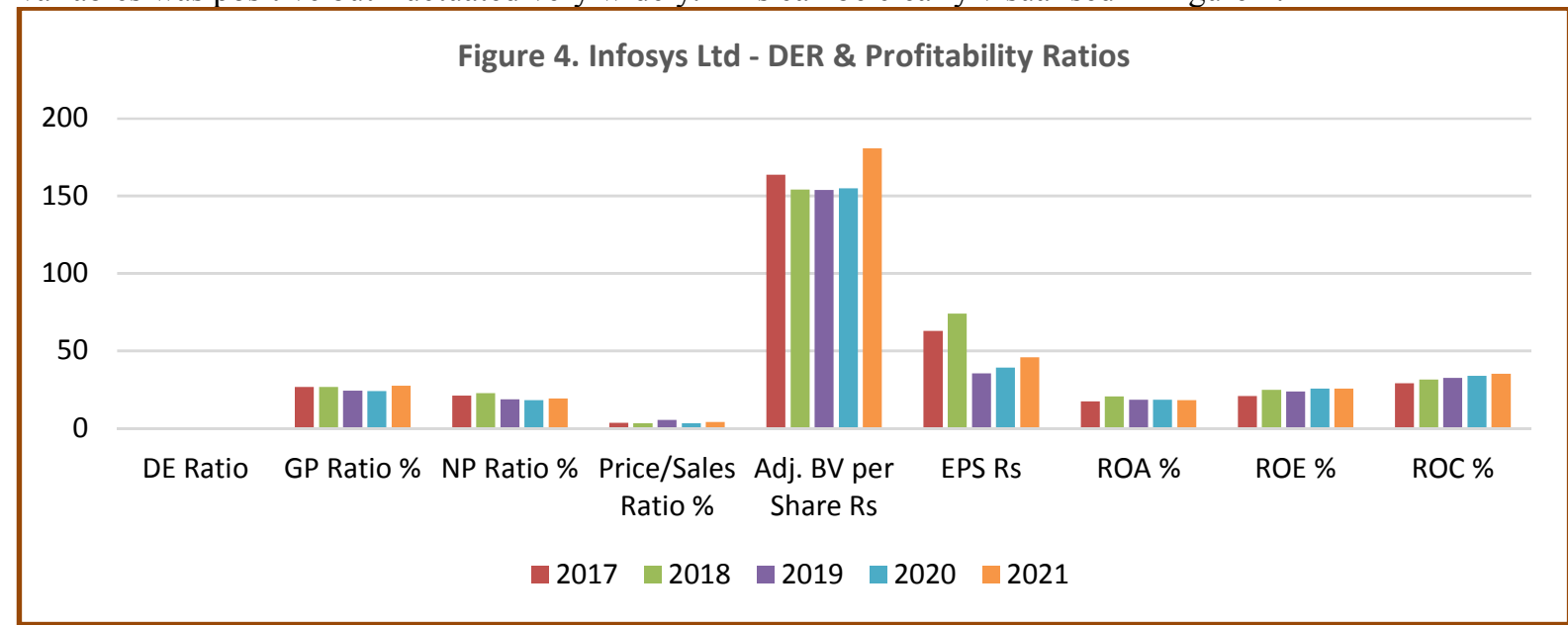

This suggests that, in the case of a profitable firm, the use of debt is immaterial in producing a profit when the vision is clear and the leadership is competent in identifying business prospects. The company's profitability has been hampered by interruptions as a result of the business environment's volatility.

7.3 The case of Reliance Industries Ltd (RIL)

The debt-equity ratio (DER) of Reliance Industries Ltd., as well as the various profitability ratios, such as gross 
profit margin in percentage, net profit margin in percentage, price (share price) to sales ratio in percentage, adjusted book value per share in rupees, earnings per share in rupees, return on assets in percentage, return on equity in percentage, and return on capital in percentage, are presented for the five fiscal years from 2017 to 2021 in table 6.

It has been discovered that the debt component has been reduced from $60 \%$ to $20 \%$ between 2017 and 2021 . The coefficient of correlation between DER and GPR, NPR, PSR, ABVPS, and ROA was shown to be negative, however only between DER and ABVPS was it significant. The relationship between DER and ROE and DER and ROC is favourable but not statistically significant.

\begin{tabular}{|c|c|c|c|c|c|c|c|c|c|}
\hline \multicolumn{10}{|c|}{ Table 6. Reliance Ind Ltd - DER \& Profitability Ratios } \\
\hline YEAR & $\begin{array}{c}\mathrm{DE} \\
\text { Ratio }\end{array}$ & $\begin{array}{c}\text { GP } \\
\text { Ratio \% }\end{array}$ & $\begin{array}{c}\text { NP } \\
\text { Ratio \% }\end{array}$ & $\begin{array}{c}\text { Price/Sales } \\
\text { Ratio \% }\end{array}$ & $\begin{array}{l}\text { Adj. BV per } \\
\text { Share Rs }\end{array}$ & $\begin{array}{c}\text { EPS } \\
\text { Rs }\end{array}$ & $\begin{array}{c}\text { ROA } \\
\%\end{array}$ & $\begin{array}{c}\mathrm{ROE} \\
\%\end{array}$ & $\begin{array}{c}\mathrm{ROC} \\
\%\end{array}$ \\
\hline 2017 & 0.6 & 16.5 & 10.7 & 1.2 & 389.7 & 101.2 & 4.8 & 11.4 & 10.6 \\
\hline 2018 & 0.5 & 18.2 & 10.2 & 2.1 & 433.8 & 60.8 & 5.4 & 12.3 & 13.1 \\
\hline 2019 & 0.5 & 16.4 & 7.7 & 1.3 & 572.1 & 67.1 & 5.6 & 10.3 & 12 \\
\hline 2020 & 0.4 & 15.8 & 7.4 & 1.5 & 663.8 & 62.7 & 5.3 & 8.9 & 11.7 \\
\hline 2021 & 0.2 & 21.7 & 13.5 & 2.9 & 1033.8 & 78.7 & 5.6 & 7.6 & 8.8 \\
\hline \multicolumn{10}{|c|}{ Source: https://www.equitymaster.com/ } \\
\hline \multicolumn{10}{|c|}{ Test of Correlation - Reliance Ind - DE R and Profitability Ratios } \\
\hline \multicolumn{3}{|c|}{ Correlation } & DE Ratio & \multicolumn{6}{|c|}{ Significant/Not Significant } \\
\hline \multicolumn{3}{|c|}{ DE Ratio } & - & \\
\hline \multicolumn{3}{|c|}{ GP Ratio \% } & -0.7729 & \multicolumn{6}{|c|}{ The P-value is 0.126123 . Not Significant at $\mathrm{p}<0.05$} \\
\hline \multicolumn{3}{|c|}{ NP Ratio \% } & -0.4967 & \multicolumn{6}{|c|}{ The P-value is 0.395419 . Not Significant at $\mathrm{p}<0.05$} \\
\hline \multicolumn{3}{|c|}{ Price/Sales Ratio \% } & -0.839 & \multicolumn{6}{|c|}{ The $\mathrm{P}$-value is 0.075648 . Not Significant at $\mathrm{p}<0.05$} \\
\hline \multicolumn{3}{|c|}{ Adj. BV per share Rs } & -0.9766 & \multicolumn{6}{|c|}{ The $\mathrm{P}$-value is 0.004447 . Significant at $\mathrm{p}<0.05$} \\
\hline \multicolumn{3}{|l|}{ EPS Rs } & 0.2443 & \multicolumn{6}{|c|}{ The $\mathrm{P}$-value is 0.075648 . Not Significant at $\mathrm{p}<0.05$} \\
\hline \multicolumn{3}{|l|}{$\mathrm{ROA} \%$} & -0.6421 & \multicolumn{6}{|c|}{ The P-value is 0.24285 . Not Significant at $\mathrm{p}<0.05$} \\
\hline \multicolumn{3}{|l|}{ ROE \% } & 0.8731 & \multicolumn{6}{|c|}{ The P-value is 0.053221 . Not Significant at $\mathrm{p}<0.05$} \\
\hline \multicolumn{3}{|l|}{$\mathrm{ROC} \%$} & 0.6295 & \multicolumn{6}{|c|}{ The P-value is 0.255135 . Not Significant at $\mathrm{p}<0.05$} \\
\hline
\end{tabular}

This implies that reduction in debt leads to a significant decrease of ABVPS and rest of the variables are not impacted by the capital structure modification.

\subsection{The case of SBI Ltd}

Table 7 displays SBI Ltd.'s debt-equity ratio (DER) as well as various profitability ratios such as gross profit margin in percentage, net profit margin in percentage, price (share price) to income ratio in percentage, adjusted book value per share in rupees, earnings per share in rupees, return on assets in percentage, return on equity in percentage, and capital adequacy ratio in percentage for the five financial years from 2017 to 2021 .

SBI's debt component was determined to be 13.5 times its equity capital in 2017 and has since been steadily grown to 15.1 times by the year 2021 .

The relationship between DER and GPR, as well as DER and PSR, was determined to be negative but not significant. Similarly, the correlation between DER and ROE and DER and CAR was shown to be positive but not statistically significant.

The correlation between DER and NPR, DER and ABVPS, DER and EPS, and DER and ROA, on the other hand, was found to be positive and significant (Addae, A. A., Nyarko-Baasi, M., \& Hughes, D. (2013) due to the effective use of debt. 
Table 7. SBI Ltd - DER \& Profitability Ratios

\begin{tabular}{|c|c|c|c|c|c|c|c|c|c|}
\hline YEAR & $\begin{array}{c}\text { DE } \\
\text { Ratio } \\
\end{array}$ & $\begin{array}{c}\text { GP } \\
\text { Ratio \% } \\
\end{array}$ & $\begin{array}{c}\text { NP } \\
\text { Ratio\% }\end{array}$ & $\begin{array}{c}\text { Price/Income } \\
\text { Ratio \% } \\
\end{array}$ & $\begin{array}{c}\text { Adj. BV per } \\
\text { Share Rs }\end{array}$ & $\begin{array}{c}\text { EPS } \\
\text { Rs }\end{array}$ & ROA \% & ROE \% & CAR $* \%$ \\
\hline 2017 & 13.5 & -2.6 & 0.1 & 0.8 & 243.4 & 0.3 & 0 & 0.1 & 13.6 \\
\hline 2018 & 13.4 & -6 & -2 & 1.1 & 258.1 & -5.1 & -0.1 & -2 & 12.7 \\
\hline 2019 & 14.3 & -6.8 & 0.9 & 1 & 262.8 & 2.6 & 0.1 & 1 & 12.9 \\
\hline 2020 & 14.4 & -8.5 & 7.3 & 0.9 & 281.3 & 22.1 & 0.5 & 7.9 & 13.1 \\
\hline 2021 & 15.1 & -10.2 & 8.1 & 0.9 & 308.8 & 25.1 & 0.5 & 8.1 & 13.8 \\
\hline
\end{tabular}

\begin{tabular}{|l|c|l|}
\hline \multicolumn{1}{|c|}{ Correlation } & DE Ratio & Significant/Not Significant \\
\hline DE Ratio & - & \\
\hline GP Ratio \% & -0.86959 & The P-value is 0.055785 . Not Significant at $\mathrm{p}<0.05$ \\
\hline NP Ratio\% & 0.882101 & The P-value is 0.047728 . Significant at $\mathrm{p}<0.05$ \\
\hline Price/Income Ratio \% & -0.21235 & The P-value is 0.732109 . Not Significant at $\mathrm{p}<0.05$ \\
\hline Adj. BV per Share Rs & 0.918263 & The P-value is 0.027687 . Significant at $\mathrm{p}<0.05$ \\
\hline EPS Rs & 0.882117 & The P-value is 0.047668 . Significant at $\mathrm{p}<0.05$ \\
\hline ROA \% & 0.88119 & The P-value is 0.048269 . Significant at $\mathrm{p}<0.05$ \\
\hline ROE \% & 0.86867 & The P-value is 0.055974 . Not Significant at $\mathrm{p}<0.05$ \\
\hline CAR \% \% & 0.470834 & The P-value is 0.42351 . Not Significant at $\mathrm{p}<0.05$ \\
\hline & \multicolumn{2}{|c|}{ Source: Computation by Author } \\
\hline
\end{tabular}

This implies that the increase in certain variables like NPR, ABVPS, EPS, and ROA is determined by the substantial increase in Debt (1300 to 1500 percent of the equity).

\subsection{The Case of Adani Enterprises}

Table 8 shows Adani Enterprises Ltd.'s debt-equity ratio (DER) as well as various profitability ratios such as gross profit margin in percentage, net profit margin in percentage, price (share price) to sales ratio in percentage, adjusted book value per share in rupees, earnings per share in rupees, return on assets in percentage, return on equity in percentage, and return on capital in percentage for the five fiscal years from 2017 to 2021.

Between 2017 and 2019, the debt component was reduced from $60 \%$ to 20\%, and was kept at 20\% in 2020, before being increased to $60 \%$ in 2021 . The relationship in most profitability ratios is not significant, regardless of whether it is positive or negative, with the exception of ROC, which is significant but negative. In general, increasing debt levels leads to increased profitability, however in the case of Adani Enterprises, the correlation between DER and ROC is the inverse.

This means that the use of debt may not be for the purpose of optimising the capital structure to reduce total capital costs and maximise profitability, but rather to fulfil capital requirements owing to a lack of alternative options.

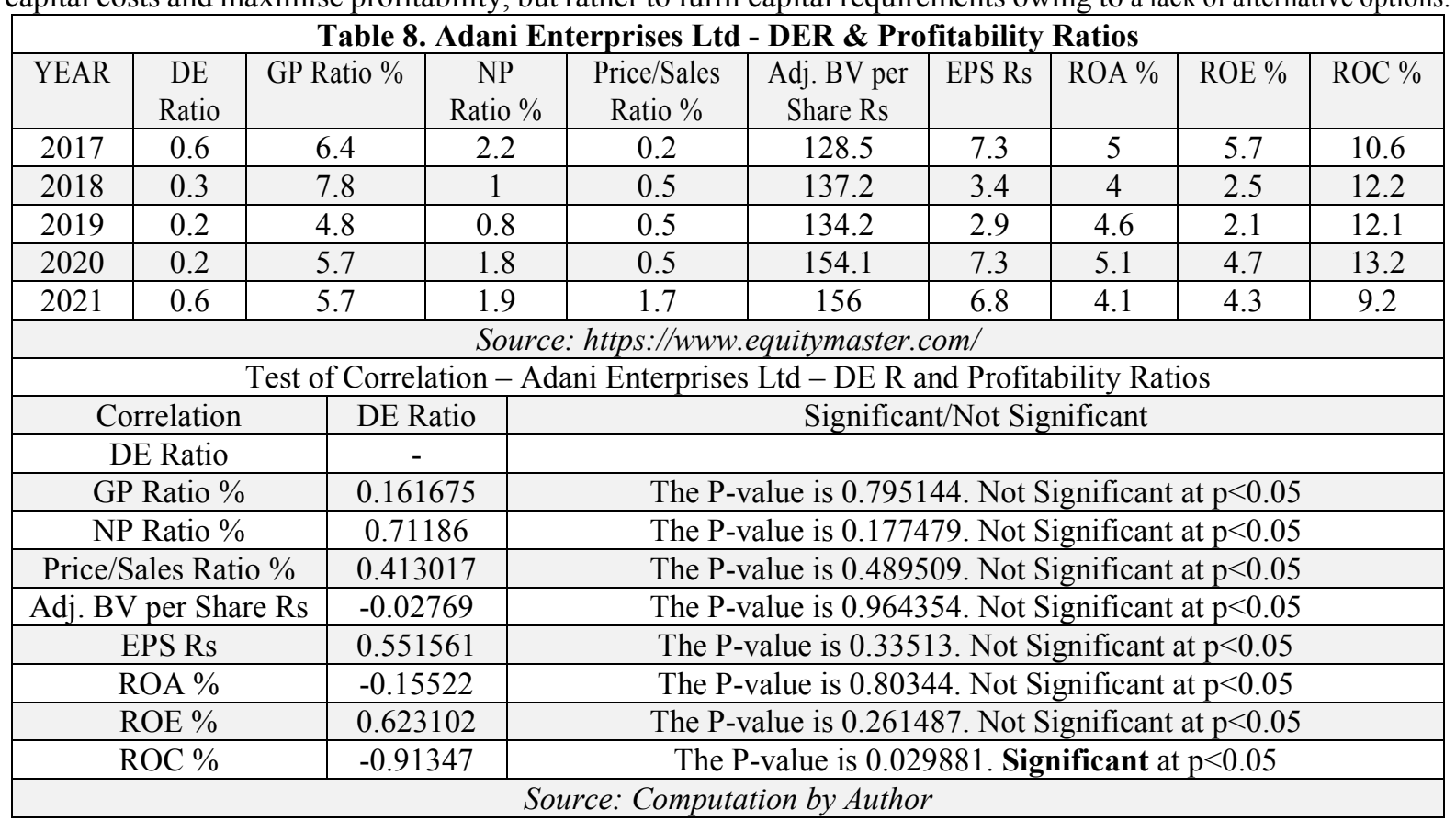




\subsection{The Case of INTERGLOBE AVIATION (INDIGO) Ltd}

For the five fiscal years from 2017 to 2021, Table 9 shows INTERGLOBE AVIATION (INDIGO) Ltd.'s debtequity ratio (DER), as well as various profitability ratios such as gross profit margin in percentage, net profit margin in percentage, price (share price) to sales ratio in percentage, adjusted book value per share in rupees, earnings per share in rupees, return on assets in percentage, return on equity in percentage, and return on capital in percentage.

From 2017 to 2020, the debt component was reduced from $60 \%$ to $10 \%$, with a sharp increase to 5 times in 2021. The relationship between DER and GPR, as well as DER and ROA, is negative but not statistically significant. There was a strong but negative association between DER and NPR, DER and PSR, DER and ABVPS, DER and EPS, DER and ROE, and DER and ROC.

This indicates that, in terms of capital structure theory, the use of debt is irrelevant. However excessive debt capital usage results in a debt crisis, in which a company struggles to repay its debts. The company will eventually go bankrupt if corrective steps are not implemented in a timely manner. A credit rating agency may reduce a company's or a country's credit rating if it is in debt (Ross, S. A et al 2009).

Indigo's earnings are hampered by the current corporate tax rate, which should be reduced by the government and policymakers. When taxes are decreased and the firm becomes more lucrative, it creates the conditions for more jobs to be created, lowering unemployment in the country. Furthermore, management might look forward to obtaining lower-cost loans or attempting to issue additional equity shares to settle debts, therefore reducing future losses.

\begin{tabular}{|c|c|c|c|c|c|c|c|c|c|}
\hline \multicolumn{10}{|c|}{ Table 9. INTERGLOBE AVIATION (INDIGO) Ltd - DER \& Profitability Ratios } \\
\hline $\begin{array}{c}\text { YEA } \\
\text { R }\end{array}$ & $\begin{array}{c}\text { DE } \\
\text { Ratio }\end{array}$ & $\begin{array}{c}\text { GP } \\
\text { Ratio \% }\end{array}$ & $\begin{array}{c}\text { NP } \\
\text { Ratio } \\
\%\end{array}$ & $\begin{array}{c}\text { Price/Sales } \\
\text { Ratio \% }\end{array}$ & $\begin{array}{c}\text { Adj. BV } \\
\text { per Share } \\
\text { Rs }\end{array}$ & EPS Rs & $\begin{array}{c}\mathrm{ROA} \\
\%\end{array}$ & ROE \% & $\begin{array}{c}\mathrm{ROC} \\
\%\end{array}$ \\
\hline 2017 & 0.6 & 11.8 & 8.9 & 1.8 & 96.7 & 45.9 & 13.6 & 44.5 & 41.7 \\
\hline 2018 & 0.3 & 13.2 & 9.7 & 2 & 182.3 & 58.3 & 12.6 & 31.9 & 38.2 \\
\hline 2019 & 0.3 & -0.5 & 0.6 & 1.5 & 179.2 & 4.1 & 2.9 & 2.3 & 4.6 \\
\hline 2020 & 0.1 & 11.4 & -0.7 & 1.4 & 152.3 & -6.1 & 3.8 & -4 & 26.5 \\
\hline 2021 & 5 & -3.5 & -39.7 & 3.5 & 2 & -150.9 & -8 & -7656.7 & -797.5 \\
\hline \multicolumn{10}{|c|}{ Source: https://www.equitymaster.com/ } \\
\hline \multicolumn{10}{|c|}{ Test of Correlation - INTERGLOBE AVIATION (INDIGO) Ltd - DE R and Profitability Ratios } \\
\hline \multicolumn{3}{|c|}{ Correlation } & DE Ratio & \multicolumn{6}{|c|}{ Significant/Not Significant } \\
\hline \multicolumn{3}{|c|}{ DE Ratio } & - & \\
\hline \multicolumn{3}{|c|}{ GP Ratio \% } & -0.70334 & \multicolumn{6}{|c|}{ The P-value is 0.185398 . Not Significant at $\mathrm{p}<0.05$} \\
\hline \multicolumn{3}{|c|}{ NP Ratio\% } & -0.9557 & \multicolumn{6}{|c|}{ The $\mathrm{P}$-value is 0.011006 . Significant at $\mathrm{p}<0.05$} \\
\hline \multicolumn{3}{|c|}{ Price/Sales Ratio \% } & 0.969342 & \multicolumn{6}{|c|}{ The P-value is 0.006427 . Significant at $\mathrm{p}<0.05$} \\
\hline \multicolumn{3}{|c|}{ Adj. BV per Share Rs } & -0.91406 & \multicolumn{6}{|c|}{ The $\mathrm{P}$-value is 0.029881 . Significant at $\mathrm{p}<0.05$} \\
\hline \multicolumn{3}{|c|}{ EPS Rs } & -0.92441 & \multicolumn{6}{|c|}{ The $\mathrm{P}$-value is 0.024862 . Significant at $\mathrm{p}<0.05$} \\
\hline \multicolumn{3}{|c|}{ ROA \% } & -0.79184 & \multicolumn{6}{|c|}{ The P-value is 0.110253 Not Significant at $p<0.05$} \\
\hline \multicolumn{3}{|c|}{ ROE \% } & -0.99593 & \multicolumn{6}{|c|}{ The P-value is 0.000304 . Significant at $\mathrm{p}<0.05$} \\
\hline \multicolumn{3}{|c|}{ ROC \% } & -0.99417 & \multicolumn{6}{|c|}{ The P-value is 0.000557 . Significant at $\mathrm{p}<0.05$} \\
\hline \multicolumn{10}{|c|}{ Source: Computation by Author } \\
\hline
\end{tabular}

\subsection{The Case of Ashok Leyland Ltd}

Table 10 displays Ashok Leyland Ltd.'s debt-equity ratio (DER) as well as various profitability ratios such as gross profit margin in percentage, net profit margin in percentage, price (share price) to sales ratio in percentage, adjusted book value per share in rupees, earnings per share in rupees, return on assets in percentage, return on equity in percentage, and return on capital in percentage for the five fiscal years from 2017 to 2021 .

During the fiscal year 2017, the debt component amounted to 140 percent (1.4 times) of the company's equity. In the year 2021, it was gradually increased to 200 percent (2 times).

The correlation coefficient is used to analyse the change in DER and its influence on the profitability ratios. The relationship between DER and NPR, DER and EPS, DER and ROA,

DER and ROE, and DER and ROC was shown to be substantial but negative. It has no impact on the other parameters.

According to capital structure theory, the use of debt and its increase to some level will enhance the company's profitability. However, in this scenario, it is acting in reverse, raising concerns about the use of debt as a component. 
Table 10. Ashok Leyland Ltd - DER \& Profitability Ratios

\begin{tabular}{|c|c|c|c|c|c|c|c|c|c|}
\hline \multicolumn{1}{|c|}{ Table 10. Ashok Leyland Ltd - DER \& Profitability Ratios } \\
\hline $\begin{array}{c}\text { YEA } \\
\text { R }\end{array}$ & $\begin{array}{c}\text { DE } \\
\text { Ratio }\end{array}$ & $\begin{array}{c}\text { GP } \\
\text { Ratio } \%\end{array}$ & $\begin{array}{c}\text { NP } \\
\text { Ratio } \%\end{array}$ & $\begin{array}{c}\text { Price/Sales } \\
\text { Ratio } \%\end{array}$ & $\begin{array}{c}\text { Adj. BV per } \\
\text { Share Rs }\end{array}$ & $\begin{array}{c}\text { EPS } \\
\text { Rs }\end{array}$ & $\begin{array}{c}\text { ROA } \\
\%\end{array}$ & $\begin{array}{c}\text { ROE } \\
\%\end{array}$ & $\begin{array}{c}\text { ROC } \\
\%\end{array}$ \\
\hline 2017 & 1.4 & 15.4 & 7.6 & 1.2 & 21.7 & 5.8 & 10.1 & 25.8 & 18.9 \\
\hline 2018 & 1.4 & 14.4 & 6.2 & 1.2 & 25 & 6.2 & 9.1 & 24.6 & 21.5 \\
\hline 2019 & 1.5 & 14.7 & 6.6 & 1.1 & 29.8 & 7.5 & 9.4 & 25 & 20.1 \\
\hline 2020 & 1.7 & 14.5 & 2.1 & 0.9 & 26.4 & 1.6 & 5.9 & 5.9 & 12 \\
\hline 2021 & 2 & 13 & -0.4 & 1.3 & 26.6 & -0.2 & 4.4 & -0.9 & 7.8 \\
\hline \multicolumn{7}{|c|}{ Source: https://www.equitymaster.com/ } \\
\hline Test of Correlation - ASHOK LEYLAND Ltd - DE R and Profitability Ratios \\
\hline \multicolumn{7}{|l|}{ Correlation } \\
\hline 8
\end{tabular}

\subsection{The Case of BASF INDIA Ltd}

For the five financial years from 2017 to 2021, Table 11 shows BASF INDIA Ltd.'s debt-equity ratio (DER) as well as various profitability ratios such as gross profit margin in percentage, net profit margin in percentage, price (share price) to sales ratio in percentage, adjusted book value per share in rupees, earnings per share in rupees, return on assets in percentage, return on equity in percentage, and return on capital in percentage.

\begin{tabular}{|c|c|c|c|c|c|c|c|c|c|c|}
\hline \multicolumn{11}{|c|}{ Table 11. BASF INDIA Ltd - DER \& Profitability Ratios } \\
\hline $\begin{array}{c}\text { YEA } \\
\text { R }\end{array}$ & $\begin{array}{c}\text { DE } \\
\text { Ratio }\end{array}$ & \multicolumn{2}{|c|}{$\begin{array}{c}\text { GP } \\
\text { Ratio \% }\end{array}$} & $\begin{array}{c}\text { NP } \\
\text { Ratio \% }\end{array}$ & $\begin{array}{c}\text { Price/Sales } \\
\text { Ratio \% }\end{array}$ & $\begin{array}{l}\text { Adj. BV per } \\
\text { Share Rs }\end{array}$ & $\begin{array}{c}\text { EPS } \\
\text { Rs }\end{array}$ & $\begin{array}{c}\text { ROA } \\
\%\end{array}$ & $\begin{array}{c}\text { ROE } \\
\%\end{array}$ & $\begin{array}{c}\text { ROC } \\
\%\end{array}$ \\
\hline 2017 & 0.6 & \multicolumn{2}{|c|}{6.1} & -0.3 & 1 & 254.4 & -3.3 & 3.3 & -1.3 & 7.2 \\
\hline 2018 & 0.2 & \multicolumn{2}{|c|}{9.1} & 4.5 & 1.5 & 310 & 56.9 & 9.3 & 18.4 & 22.5 \\
\hline 2019 & 0.2 & \multicolumn{2}{|c|}{4.6} & 1.4 & 1.2 & 325.8 & 18.9 & 6.5 & 5.8 & 13.9 \\
\hline 2020 & 0.1 & \multicolumn{2}{|c|}{3.2} & 0.3 & 0.7 & 286.6 & 5.3 & 3.4 & 1.8 & 10.8 \\
\hline 2021 & 0 & \multicolumn{2}{|c|}{10.8} & 5.8 & 0.7 & 411.6 & 127.7 & 11 & 31 & 49.2 \\
\hline \multicolumn{11}{|c|}{ Source: https://www.equitymaster.com/ } \\
\hline \multicolumn{11}{|c|}{ Test of Correlation - BASF INDIA Ltd - DE R and Profitability Ratios } \\
\hline \multicolumn{3}{|c|}{ Correlation } & \multicolumn{2}{|c|}{ DE Ratio } & \multicolumn{6}{|c|}{ Significant/Not Significant } \\
\hline \multicolumn{3}{|c|}{ DE Ratio } & \multicolumn{2}{|r|}{-} & \multicolumn{6}{|c|}{-} \\
\hline \multicolumn{3}{|c|}{ GP Ratio \% } & \multicolumn{2}{|r|}{-0.24957} & \multicolumn{6}{|c|}{ The P-value is 0.685038 . Not Significant at $p<0.05$} \\
\hline \multicolumn{3}{|c|}{ NP Ratio \% } & \multicolumn{2}{|r|}{-0.63247} & \multicolumn{6}{|c|}{ The P-value is 0.251679 . Not Significant at $\mathrm{p}<0.05$} \\
\hline \multicolumn{3}{|c|}{ Price/Sales Ratio \% } & \multicolumn{2}{|c|}{0.282051} & \multicolumn{6}{|c|}{ The $\mathrm{P}$-value is 0.645642 . Not Significant at $\mathrm{p}<0.05$} \\
\hline \multicolumn{3}{|c|}{ Adj. BV per Share Rs } & \multicolumn{2}{|c|}{-0.76184} & \multicolumn{6}{|c|}{ The $\mathrm{P}$-value is 0.134293 . Not Significant at $\mathrm{p}<0.05$} \\
\hline \multicolumn{3}{|c|}{ EPS Rs } & & -0.6442 & The $\mathrm{P}$-value is 0 & 2409. Not Sign & ficant a & $<0.05$ & & \\
\hline $\mathrm{ROA} \%$ & & & & 0.59978 & The $\mathrm{P}$-value is 0 & 284757. Not S & snifican & it $\mathrm{p}<0.0$ & & \\
\hline ROE \% & & & & 0.65594 & The $\mathrm{P}$-value is 0 & 229289. Not S & snifican & it $\mathrm{p}<0.0$ & & \\
\hline $\mathrm{ROC} \%$ & & & & 0.65611 & The $\mathrm{P}$-value is & 229289. Not & nifica & it $\mathrm{p}<0.0$ & & \\
\hline & & & & & Source: Comput & ion by Author & & & & \\
\hline
\end{tabular}

During the fiscal year 2017, debt represented $60 \%$ of the company's equity, which steadily fell to $20 \%$ in 2018, was maintained at the same level in 2019, and further lowered to $10 \%$ in 2020 and zero in 2021.

The correlation coefficient is used to examine the impact of changes in DER on-profitability ratios. Regardless of the dynamics in the company's capital structure, the relationship is found to be inconsequential.

\subsection{The Case of Chambal Fertilisers Ltd}

Table 12 shows the debt-equity ratio (DER) and other profitability ratios for Chambal Fertilisers Ltd. for the five financial years from 2017 to 2021, including gross profit margin in percentage, net profit margin in percentage, price (share price) to sales ratio in percentage, adjusted book value per share in rupees, earnings per share in rupees, 
return on assets in percentage, return on equity in percentage, and return on capital in percentage.

\begin{tabular}{|c|c|c|c|c|c|c|c|c|c|}
\hline \multicolumn{10}{|c|}{ Table 12. Chambal Fertilisers Ltd - DER \& Profitability } \\
\hline YEA & $\mathrm{DE}$ & \multirow{2}{*}{$\begin{array}{c}\text { GP } \\
\text { Ratio \% }\end{array}$} & NP & Price/Sales & Adj. BV per & EPS & ROA & ROE & ROC \\
\hline $\mathrm{R}$ & Ratio & & Ratio \% & Ratio \% & Share Rs & Rs & $\%$ & $\%$ & $\%$ \\
\hline 2017 & 0.7 & 8.9 & 4.7 & 0.4 & 50.4 & 8.6 & 7.6 & 17 & 20.5 \\
\hline 2018 & 1.4 & 10.7 & 6 & 0.7 & 59.6 & 11 & 6.5 & 18.4 & 14.4 \\
\hline 2019 & 1.5 & 9.9 & 4.6 & 0.7 & 69.2 & 11.2 & 5.2 & 16.3 & 13.3 \\
\hline 2020 & 1.2 & 16.5 & 10 & 0.5 & 85 & 29.4 & 12 & 34.6 & 23.2 \\
\hline 2021 & 0.6 & 11.9 & 13 & 0.6 & 126 & 39.8 & 18.9 & 31.6 & 30.4 \\
\hline \multicolumn{10}{|c|}{ Source: https://www.equitymaster.com/ } \\
\hline \multicolumn{10}{|c|}{ Test of Correlation - Chambal Fertilisers Ltd - DE R and Profitability Ratios } \\
\hline \multicolumn{3}{|c|}{ Correlation } & DE Ratio & \multicolumn{6}{|c|}{ Significant/Not Significant } \\
\hline \multicolumn{3}{|c|}{ DE Ratio } & - & \\
\hline \multicolumn{3}{|c|}{ GP Ratio \% } & 0.096667 & & & & \multicolumn{3}{|c|}{ The $\mathrm{P}$-value is 0.877197 . Not Significant at $\mathrm{p}<0.05$} \\
\hline \multicolumn{3}{|c|}{ NP Ratio \% } & -0.49122 & \multicolumn{6}{|c|}{ The P-value is 0.400956 . Not Significant at $\mathrm{p}<0.05$} \\
\hline \multicolumn{3}{|c|}{ Price/Sales Ratio \% } & 0.647495 & \multicolumn{6}{|c|}{ The $\mathrm{P}$-value is 0.237012 . Not Significant at $\mathrm{p}<0.05$} \\
\hline \multicolumn{3}{|c|}{ Adj. BV per Share Rs } & -0.43851 & \multicolumn{6}{|c|}{ The P-value is 0.45956 . Not Significant at $\mathrm{p}<0.05$} \\
\hline \multicolumn{3}{|c|}{ EPS Rs } & -0.46863 & \multicolumn{6}{|c|}{ The $\mathrm{P}$-value is 0.425528 . Not Significant at $\mathrm{p}<0.05$} \\
\hline \multicolumn{3}{|c|}{ ROA \% } & -0.68668 & \multicolumn{6}{|c|}{ The $\mathrm{P}$-value is 0.200045 . Not Significant at $\mathrm{p}<0.05$} \\
\hline \multicolumn{3}{|c|}{$\mathrm{ROE} \%$} & -0.33012 & \multicolumn{6}{|c|}{ The $\mathrm{P}$-value is 0.587587 . Not Significant at $\mathrm{p}<0.05$} \\
\hline \multicolumn{3}{|c|}{$\mathrm{ROC} \%$} & -0.82555 & \multicolumn{6}{|c|}{ The P-value is 0.084817 . Not Significant at $\mathrm{p}<0.05$} \\
\hline \multicolumn{10}{|c|}{ Source: Computation by Author } \\
\hline
\end{tabular}

During the fiscal year 2017, debt accounted for 70\% of the company's equity, which rapidly increased to 140 percent in 2018, then to 150 percent in 2019, before declining to 120 percent in 2020 and eventually to $60 \%$ in 2021 .

Changes in DER have an influence on profitability ratios, and the correlation coefficient is utilised to investigate this. The correlation is determined to really be insignificant regardless of the dynamics in the company's financial or capital structure.

\subsection{The case of GLENMARK PHARMA Ltd}

Table 13 shows the debt-equity ratio (DER) and other profitability ratios of GLENMARK PHARMA Ltd. for the five fiscal years from 2017 to 2021, including gross margin as a percentage, net profit margin as a percentage, price (share price) to sales as a percentage, adjusted book value per share in rupees, earnings per share in rupees, asset return as a percentage, return on equity as a percentage and return on capital as a percentage.

In 2017 , the debt component was determined to be 100 percent of the equity, then progressively decreased to 80 percent in 2018, 60 percent in 2019 , and a modest increase to 70 percent of the equity in 2020 . It was cut to $60 \%$ once again in 2021 .

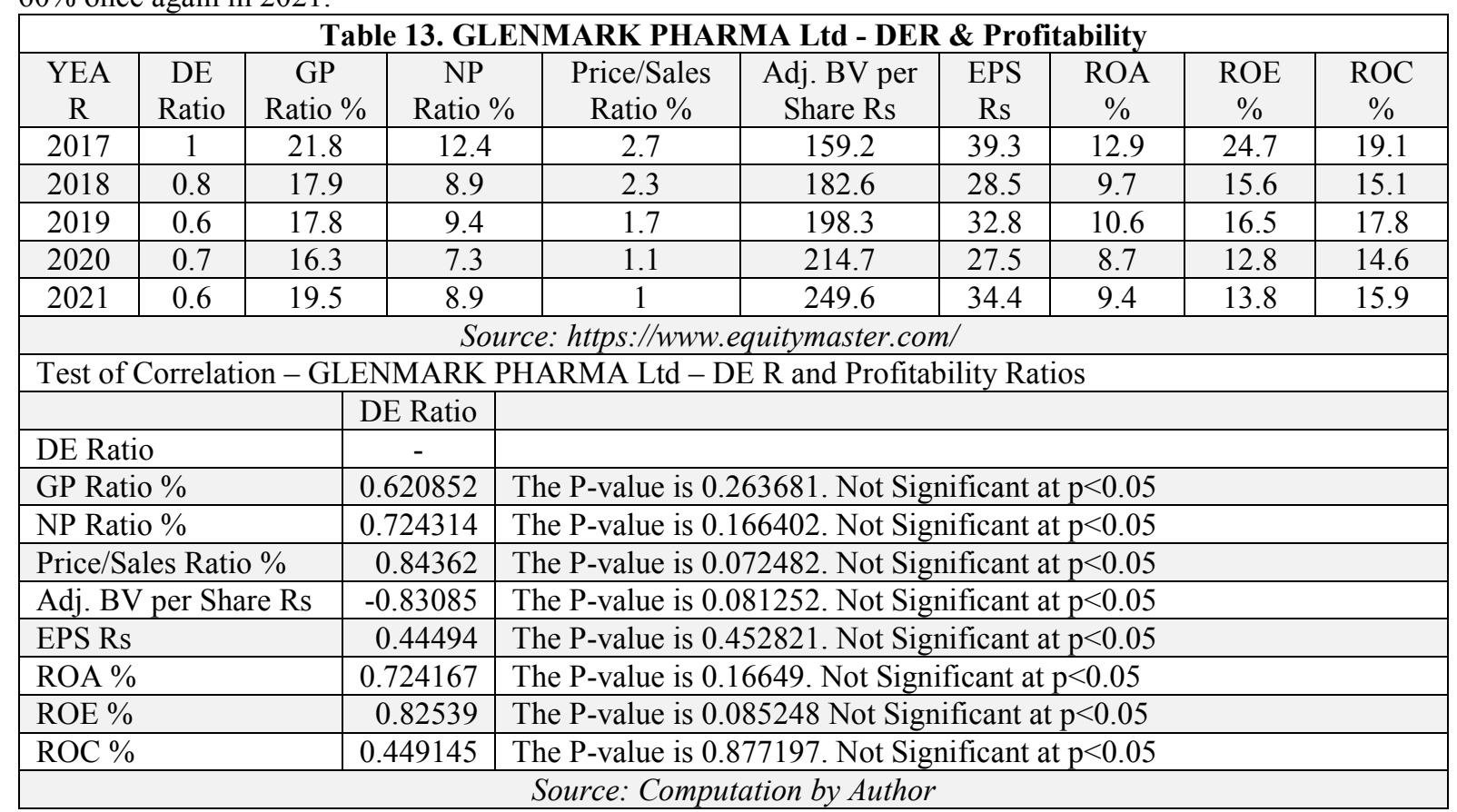


The correlation coefficient is used to assess if changes in DER have an impact on profitability ratios. Regardless of the company's financial or capital structure dynamics, the correlation is proven to be inconsequential in the GLENMARK PHARMA Ltd.

\section{IMPLICATIONS OF THE STUDY}

Based on the above-stated analyses, the summary results are presented in Table 14.

The debt component is seen to be negligible in the best IT organisations. As a result, TCS Ltd and Infosys Ltd have no debt component. The businesses have been performing really well. Companies are not seeking the benefits of capital structure manipulation because management is content with the firm's equity and internal cash reserves. When it comes to their profitability and growth, the capital structure has little bearing on their financing decisions.

Although Reliance Industries Ltd has a debt component, the impact of capital structure on adjusted book value per share was determined to be significant (ABVPS) but in a negative direction. This suggests that, because the debt component is gradually reduced, the impact on the other profitability measures is unlikely to be significant. To focus and take advantage of financial leverage benefits, a strategic finance decision support system and robotic financial analytics are recommended to check whether debt financing can further be minimised and look for other cost-effective financing options to yield positive and strong profits to the equity stakeholders

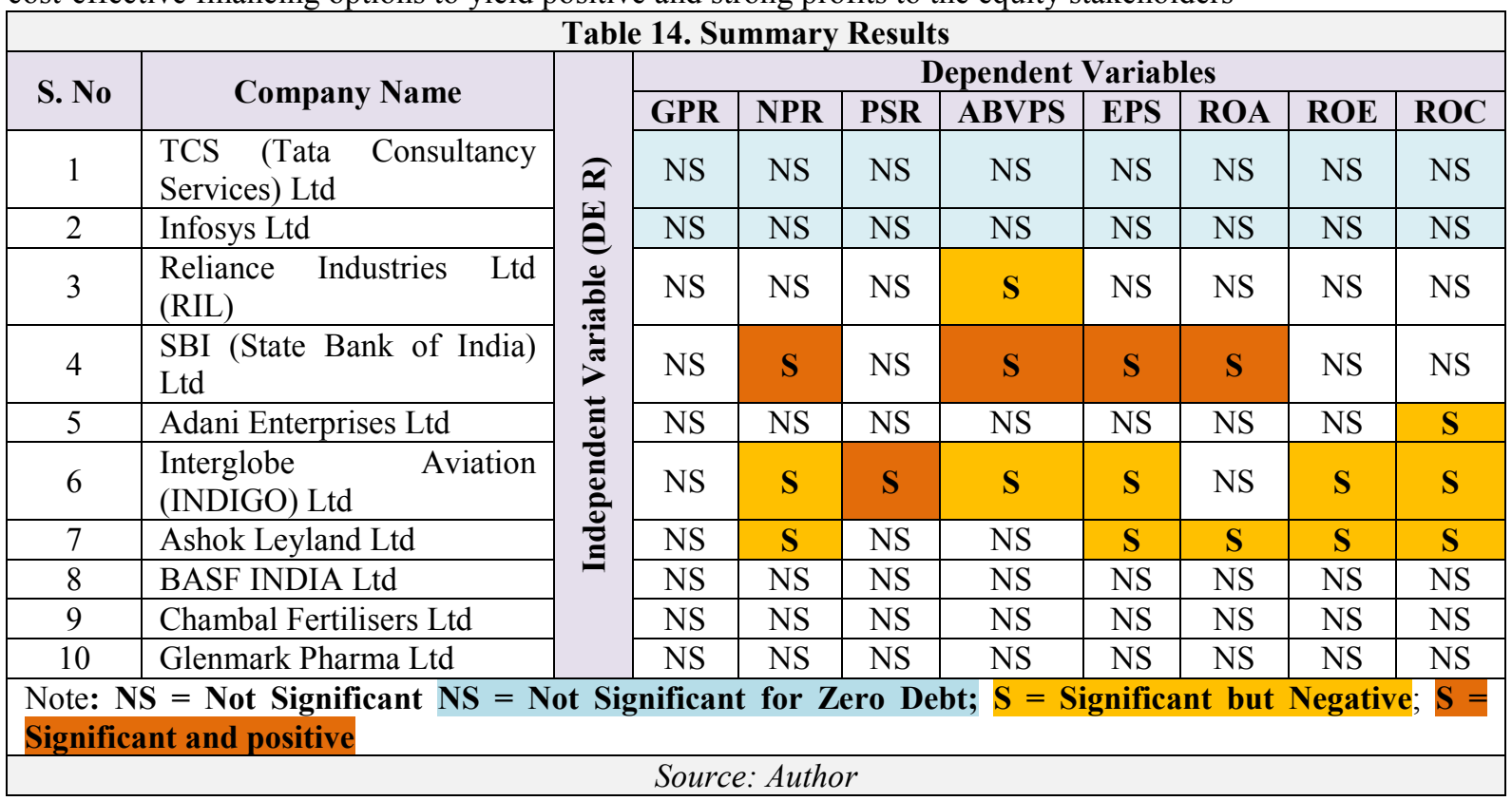

In the case of SBI Ltd, the impact of DE R is considered to have a substantial and favourable influence on NPR, ABVPS, EPS, and ROA. The DE R has no substantial impact on GPR, share price to income ratio (percent), ROE, or ROC. SBI Ltd borrows between 1300 and 1500 percent of its equity capital. Despite the fact that debt appears to be used excessively, it is used effectively to get leverage benefits. Robotic financial analytics is advised for tracing the best debt-to-equity ratio and limiting debt to its optimal level in order to maximise earnings for the bank's equity shareholders.

The debt component of Adani Enterprises Ltd was steadily lowered before being abruptly increased. In the same way, profitability ratios are subject to large swings. However, the impact of DE R is only substantial in the negative direction in ROC, and it is not significant elsewhere. This calls for a systematic and strategic inquiry to check whether debt can be replaced with other sources of cost-effective financing.

Interglobe Aviation (Indigo) Ltd.'s debt proportion was steadily lowered from $60 \%$ to $10 \%$ before being unexpectedly boosted to $500 \%$ in 2021 . DE R has a large and beneficial effect on PSR. However, DE R has a negligible effect on GPR and ROA. Capital structure has a strong negative influence on NPR, ABVPS, RPS, ROE, and ROC. The majority of profitability metrics are strongly influenced in a negative manner, necessitating an analysis to justify the use of debt as a key component of capital structure or to provide other cost-effective sources of capital to replace the debt.

From 2017 to 2021, Ashok Leyland Ltd steadily increased its debt from 140 percent to 200 percent. The effects of DE R on GPR, PSR, and ABVPS were determined to be minor and insignificant. However, the impact of DE R is large on NPR, EPS, ROA, ROE, and ROC, but in a negative direction, necessitating a reorganisation and diminution of the debt component to the bare minimum to avoid future massive losses to the establishment's equity stockholders.

BASF INDIA Ltd progressively reduced its debt from $60 \%$ to zero in 2018 , but a debt of $20 \%$ of equity 
remained in 2019, which was increased to $100 \%$ in 2020 and then to zero in 2021 . Despite the capital structure's numerous adjustments, none of the eight profitability measures were affected. As a result, management may decide to look into short-term cost-effective funding solutions depending on its needs in order to give equity owners more benefits.

In 2017, Chambal Fertilisers Ltd had a debt component of $70 \%$ of company equity, which was raised to 140 percent in 2018. This was enhanced to 150 percent in 2019, then dropped to 120 percent in 2020 , before finally being redeemed to 60 percent in 2021 . However, the influence of capital structure was found to be minor on all eight measures of the company's profitability, prompting more investigation to see whether the debt is being jeopardised in order to invalidate its cost and reduce the load on the company's profitability.

In 2017, Glenmark Pharma Ltd had a debt-to-equity ratio of 100 percent. This was progressively reduced to 80 percent in 2018 and 60 percent in 2019, with a little rise to 70 percent in 2020 and 60 percent in 2021 . Regardless of the changes in the debt-equity ratio, none of the company's eight profitability criteria have been affected significantly. This draws management's attention prompting them to reconsider the necessity for long-term debt with high coupon rates of interest when, instead, they might look into more cost-effective financing options to boost the company's bottom line.

\section{CONCLUSION}

The debt component is regarded as negligible in the best IT organisations. Companies do not seek the benefits of capital structure manipulation. None of the eight profitability criteria were impacted by the different capital structure adjustments in the majority of the selected firms. This gets management's attention, prompting them to reconsider the need for long-term debt with high coupon rates of interest when alternative, more cost-effective financing options exist. In order to focus and take advantage of financial leverage benefits, a strategic finance decision support system and robotic financial analytics are recommended for looking for cost-effective financing options.

\section{SCOPE FOR FUTURE RESEARCH}

The following topics have been suggested for further research:

10.1 The impact of bank capital structure on financial performance: a comparison of private and public sector banks.

10.2A comparison of the impacts of capital structures on financial performance for Profit-making and loss-incurring companies.

10.3Debt-equity and profit margins - manufacturing vs. service offering corporations.

10.4The effect of capital structure on profitability — a comparison of the selected companies of the BRICS nations.

\section{BIBLIOGRAPHY}

Abor J. (2005). The Effect of Capital Structure on Profitability: An Empirical Analysis of Listed Firms in Ghana. The Journal of Risk Finance, 6 (5): 438-445.

Addae, A. A., Nyarko-Baasi, M., \& Hughes, D. (2013). The Effects of Capital Structure on Profitability of Listed Firms in Ghana. European Journal of Business and Management, 5(31): 215-230.

Ali, A., \& Faisal, S. (2020, 7 30). Capital structure and financial performance: A case of Saudi Petrochemical Industry. Journal of Asian Finance, Economics, and Business, 7(7): 105-112.

Alqirem, R., et al (2020). Ownership structure, earnings manipulation, and organizational performance: The case of Jordanian Insurance Organizations. The Journal of Asian Finance, Economics, and Business, 7(12): 293308.

Anarfo, E.B. and Appiahene, E. (2017). The Impact of Capital Structure on Banks' Profitability in Africa. Journal of Accounting and Finance. 17(3): 55-66.

Chandrika P D \& RabindraKumar S (2018). Influence of capital structure on financial performance. Parikalpana - KIIT Journal of Management. 14(I): 161-170.

Chechet, I. L., \& Olayiwola, A. B. (2014). Capital structure and profitability of Nigerian quoted firms: The agency cost theory perspective. American International Journal of Social Science, 3(1): 139-158.

CO Huong Thi Thanh, et al (2021). The Impact of Capital Structure on Firm's Profitability: A Case Study of the Rubber Industry in Vietnam. THE JOURNAL OF ASIAN FINANCE, ECONOMICS AND BUSINESS. 8 (7): 469-476.

Dawar, V. (2014). Agency theory, capital structure and firm performance: some Indianevidence. Managerial Finance. 40 (12): 1190-1206.

El - Sayed Ebaid, I. (2009). The impact of capital - structure choice on firm performance: empirical evidence from Egypt. Journal of Risk Finance. 10 (5): 477-487. 
Gambo, E. M. J, Abdul-Rahman, A \& Ahmad, M. M. (2016). Capital structure and firm performance in the Nigerian cement industry. Archives of Business Research. 4(6): 30-44.

Goyal A.M. (2013). Impact of Capital Structure on Performance of Listed Public Sector Banks in India. International Journal of Business and Management Invention. 2 (10): 35-43.

Hajisaaid, A. (2020) The Effect of Capital Structure on Profitability of Basic Materials Saudi Arabia Firms. Journal of Mathematical Finance 10: 631-647.

Hamid, M.A., Abdullah, A. and Kamaruzzaman, N.A. (2015) Capital Structure and Profitability in Family and Non-Family Firms: Malaysian Evidence. Procedia Economics and Finance, 31, 44-55.

Herciu, M., \& Ogrean, C. (2017). Does capital structure influence company profitability? Studies in Business and Economics. 12(3): 50-62.

Javed, T., Younas, W., \& Imran, M. (2019). Impact of capital structure on firm performance: Evidence from Pakistani firms. International Journal of Academic Research in Economics and Management Sciences, 3(5): $28-52$.

Khalid Ashraf CHISTI, Khursheed ALI \& Mouh-i-Din SANGMI, (2013). Impact of Capital Structure on Profitability Of Listed Companies (Evidence From India), The USV Annals of Economics and Public Administration, Stefan cel Mare University of Suceava, Romania, Faculty of Economics and Public Administration, 13 (1/17): 183-191.

Movalia, N.P. (2015). A Study on Capital Structure Analysis and Profitability of Indian Tyres Industry. Pacific Business Review International. 8 (3): 78-82.

Myers, S. C. (1984). The Capital Structure Puzzle. The Journal of Finance. 39 (3): 575-592.

Narinder Pal Singh \& Mahima Bagga (2019). The Effect of Capital Structure on Profitability: An Empirical Panel Data Study. Jindal Journal of Business Research 8(1): 65-77.

Nasimi, A. N. (2016). Effect of capital structure on firm profitability (empirical evidence from London, UK). Global Journal of Management and Business Research. 16(4): 9-19.

Ngo, T. V., Tram, H. T., \& Vu, T. B. (2020). The impact of debt on corporate profitability: Evidence from Vietnam. The Journal of Asian Finance, Economics, and Business. 7(11): 835-842.

Qayyum, N. U., \& Noreen, U. (2019). Impact of capital structure on profitability: A comparative study of Islamic and conventional banks of Pakistan. The Journal of Asian Finance, Economics, and Business. 6(4), 65-74.

Reema Monga (2018). Impact of capital structure on profitability with special reference to telecom sector in India. International Journal of Creative Research Thoughts (IJCRT). 6 (2): 394-400.

Riaz, S (2015). Impact of Capital Structure on Firm's Financial Performance: An Analysis of Chemical Sector of Pakistan. Journal of Poverty, Investment and Development. 12: 85-93.

Ross, S. A., Westerfield, R. W., \& Jordan, B. D. (2001). Essentials of corporate finance. $3^{\text {rd }}$ ed. New York, McGraw-Hill.

Ross, S. A., Westerfield, R. W., Jaffe, J. F., \& Jordan, B. D. (2009). Corporate Finance: Core principles and applications. $2^{\text {nd }}$ ed. New York, McGraw-Hill Irwin.

Seadin Xhaferi \& Besa Xhaferi (2015). Alternative theories of capital structure. European Scientific Journal. 11 (7): 327-343.

Semuel, H \& Widjojo, L (2016). The Effect of Capital Structure on Profitability of Property and Construction Companies in Indonesia. Journal of Business Management. 2 (5): 12-20.

Sorana Vătavu (2015). The impact of capital structure on financial performance in Romanian listed companies. Procedia Economics and Finance. 32: 1314-1322.

Tailab, M. (2014). The Effect of Capital Structure on Profitability of Energy American Firms. International Journal of Business and Management Invention. 3 (12): 54-61.

Taqi M, Ajmal M \& Parvez A (2016). Impact of capital structure on profitability of selected trading companies of India. Arabian Journal of Business and Management Review (Oman Chapter). 6 (3): 1-16.

Yegon, C., et al. (2014) The Effects of Capital Structure on Firm's Profitability: Evidence from Kenya's Banking Sector. Research Journal of Finance and Accounting. 5 (9): 152-159.

Zeitun, R., \& Tian, G. G. (2007). Capital structure and corporate performance: Evidence from Jordan. Australasian Accounting Business \& Finance Journal, 1(4), 40-60. 